\title{
PROGNOSTICATION OF NOISE EXPOSURE RISK ON WORKERS' SAFETY AND HEALTH IN LITHUANIA
}

\author{
Ričardas BUTKUS, Alvidas ŠARLAUSKAS, Gediminas VASILIAUSKAS \\ Institute of Agricultural Engineering and Safety, Aleksandras Stulginskis University, Studentu g. 15b, \\ 53361 Akademija, Kaunas distr., Lithuania
}

Submitted 26 Sep. 2013; accepted 14 Apr. 2014

\begin{abstract}
This study explores the association between the levels of noise exposure at various sectors of economic activity and the percentage distribution of workplaces where these levels can occur. The results of the research are based on statistical data which was collected at various workplaces at the sectors of construction, transport, agriculture and forestry, electricity, water and gas supply etc. These results include the mathematical analysis of noise levels at 748 workplaces. These workplaces were sectioned by economic activity sector and percentage distribution was calculated as a ratio between the actual and total number of places where the respective noise level was exceeded. Probability index was calculated as a descriptive parameter for the evaluation of workplaces at various levels of noise exposure level normalized to a nominal 8 hour working day $\left(L_{\mathrm{EX}, 8 \mathrm{~h}}\right)$. Results show that highest number of workplaces where $L_{\mathrm{EX}, 8 \mathrm{~h}}$ was exceeded was at the companies of wood processing and furniture manufacturing. $L_{\mathrm{EX}, 8 \mathrm{~s}}$ of $80 \mathrm{~dB}(\mathrm{~A})$ was exceeded at $77 \%, L_{\mathrm{EX}, 8 \mathrm{~h}}=85 \mathrm{~dB}(\mathrm{~A})-72 \%$ and $L_{\mathrm{EX}, 8 \mathrm{~h}}=87 \mathrm{~dB}(\mathrm{~A})-68 \%$ of all the workplaces. This shows that hearing loss occurrence is likely and it can be assessed as "very risky" or "potentially risky" at the companies of wood, metal and textile sectors (probability index's values from 0,087 to 0,032 respectively).
\end{abstract}

Keywords: noise, noise exposure, risk assessment, sector of economic activity.

\section{Introduction}

Noise is one of the most common environmental issues in both working and living environments. Environmental noise is usually discussed from various perspectives, but commonly narrows to the analysis of single noise sources such as transport (Oškinis et al. 2004; Vasarevičius, Graudinyte 2004), noise in populated agglomerations (Baltrènas et al. 2010) or to biological and psychological effects on humans (Selander et al. 2009). Majority of the scientific research are related to the noise exposure at various workplaces and reviews the guidelines for noise reduction (Miyakita et al. 2004; Granneman et al. 2004), improvement of noise assessment methodology (Cagno et al. 2005) or the use of hearing protection and assessment of its effectiveness (Arezes, Miguel 2005).

There are very few scientific studies, where noise risk on operator was assessed and most of these publications usually narrow to the analysis of single measurements or the examples of a good practice. This shows the necessity to perform deeper analysis of expected noise levels on workers' health and to analyse these cases statistically.
However, the registered cases of noise induced hearing loss (NIHL) at various countries show the lack of vibroacoustic safety at work.

According to the data obtained by State Labour Inspectorate of the Republic of Lithuania, the dynamics of occupational diseases during the period 1998-2011 show the domination of NIHL (approximately 25-40\% of all occupational diseases). According to the data of European Agency for Safety and Health at Work these results are similar to the cases of NIHL registered in Finland (34.5\% at 2009 and $26.5 \%$ at 2010 respectively) (Oksa et al. 2012; Yränheikki, Savolainen 2000).

Noise exposure levels and its effects on workers' health are restricted by legal legislations such as the EU directive 2003/10/EC "On the minimum health and safety requirements regarding the exposure of workers to the risks arising from physical agents (noise)". The requirements of this directive are transferred to the laws of EU member states and obligate the employers to assess the occupational risk and to foresee the possibilities to reduce noise risk on workers. However, exposure to noise can

Corresponding author: Gediminas Vasiliauskas

E-mail: gediminas.vasiliauskas@asu.lt 
have a number of physiological and psychological effects, therefore in situ analysis is usually necessary. According to the measurement results in a particular workplace it is possible to plan preventative actions and to calculate the expenses considering the effect of most probable risk factors and its effects on workers.

Assessment of risk at workplaces can be calculated by adapting statistical methods that enable to express expected risk level in numerous values. There has been an investigation carried out by Merkevičius et al. (2011) where these guidelines were used for prognostication of vibration risk on operators of agricultural machinery.

According to Ising and Kruppa (2004), quality of the evidence associating noise exposure and health hazards can be classified to one of three categories:

- Sufficient;

- Limited;

- Inadequate.

International standard ISO 1999 indicates that occupational NIHL is not expected to occur below $L_{\mathrm{EX}, 8 \mathrm{~h}}=$ $80 \mathrm{~dB}(\mathrm{~A})$ with reference to 40 working hours per week. Higher exposure levels will increase the risk of permanent hearing threshold shift. Higher noise levels can cause different stress reactions that may lead to derangement of normal neuro-vegetative and hormonal processes and cause adverse effects on the vital body functions. These include cardiovascular parameters such as blood pressure, cardiac function, serum cholesterol and others (Babisch 2000). For noise levels exceeding $60 \mathrm{~dB}(\mathrm{~A})$, the myocardial infarction risk increases continuously, and is equal or greater than 1.2 for noise levels of $70 \mathrm{~dB}(\mathrm{~A})$.

Exposure to noise according to Haines et al. (2001) is associated with higher number of accidents (low level noise increase the number by $7.4 \%$, high level noise by $16.5 \%$ ), frequent injuries (low level noise $9.1 \%$ and high

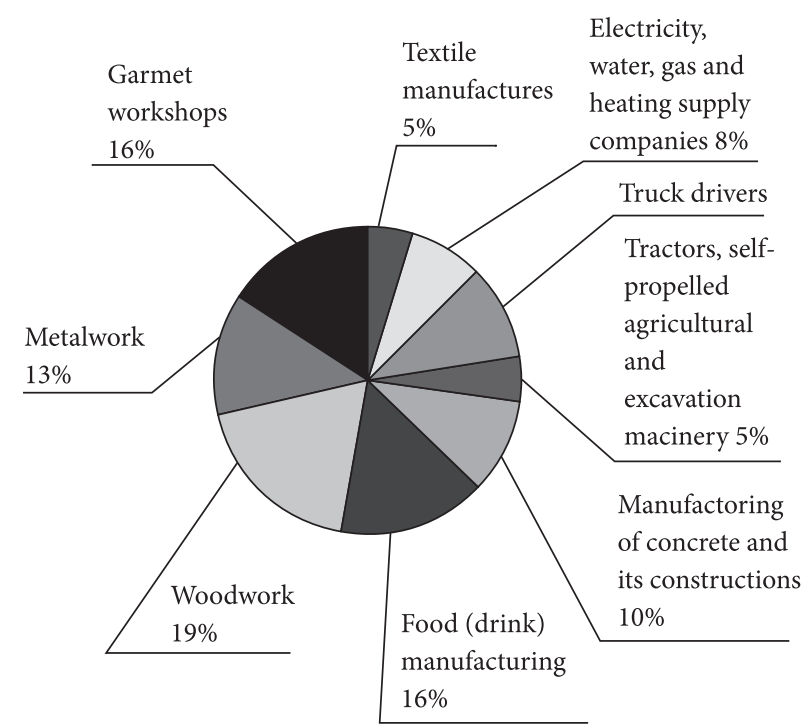

Fig. 1. Percentage distribution of workplace data used for statistical analysis $(n=748)$ level noise $26.2 \%$ ) and cognitive failures (11.2\% and $17.3 \%$ respectively).

The aim of this study was to prognosticate the noise risk on workers of various economic activity sectors in Lithuania.

\section{Methodology}

Analysis of noise exposure was done by grouping the statistical data of physically measured A-weighted noise levels by the sector of economic activity. These results were compared to the levels given by EU directive 2003/10/ EC which defines $L_{\mathrm{EX}, 8 \mathrm{~h}}$, peak sound pressure level and $\mathrm{C}$-weighted instantaneous noise pressure as risk predictors. Calculated values of $L_{\mathrm{EX}, 8 \mathrm{~h}}$ were taken as a base for assessment while peak values were considered insignificant. Main reason for elimination of peak values was that some collected data did not have all required acoustic parameters. Analysis of collected data also showed that only for $\leq 5 \%$ of all workplaces peak values were significant. This allowed using equivalent continuous A-weighted sound pressure level (SPL) as a single measure for the calculation of $L_{\mathrm{EX}, 8 \mathrm{~h}}$. These results enabled to define total noise parameter, which describes the overall number of workplaces $(\mathrm{N}, \%)$ where $\mathrm{L}_{\mathrm{EX}, 8 \mathrm{~h}}$ may exceed the levels of 80 , 85 and $87 \mathrm{~dB}(\mathrm{~A})$. These values were described as a lower exposure, upper exposure action and exposure limit value respectively.

As the base of this study all workplaces were partitioned into 5 subcategories by economic activity sector. Manufacturing sector was additionally divided into $5 \mathrm{mi}-$ nor groups. These groups were selected because of high number of workers under the sway of noise in manufacturing.

1. Construction - manufacturing and installation of concrete and its constructions;

2. Manufacturing:

1) food (including drinks);

2) wood processing and furniture trade;

3) metal processing (without foundries);

4) the garment industry;

5) textile sector;

3. Transport - workplaces of truck drivers;

4. Agriculture and Forestry - workplaces of tractors and self-propelled agricultural machinery;

5. Electricity, water, gas and heat supply services - repair and maintenance.

Statistical analysis was performed by analysing the data of 748 workplaces, where the noise exposure was investigated under the requirements of ISO 9612:2009. Percentage distribution of workplaces is shown in Figure 1.

Software package "Statistica" was used for the data analysis. Equivalent SPL's as well as number of workplaces were grouped in a frequency tables for different economic 
activities. These characteristics were later mathematically described as a third degree polynomial equation as follows:

$$
N=a \cdot L_{A, e q}^{3}+b \cdot L_{A, e q}^{2}+c \cdot L_{A, e q}+d,
$$

where $a, b, c$ ir $d$ - regression coefficients.

For the conformance of the model to the data, determination coefficients $R^{2}$ were calculated (Table 1). Further investigation of equivalent SPL distribution at workplaces $\left(N_{L}, \%\right)$ was carried out by implementing the descending percentage distribution model. Intermediate results of this analysis are shown in Figure 2.

Generalization of research results was done by calculating percentage distribution of the workplaces according to calculated noise parameters N80, N85 and N87 i.e. where $L_{\mathrm{EX}, 8 \mathrm{~h}}$ of 80,85 and $87 \mathrm{~dB}(\mathrm{~A})$ was exceeded. These results were based on assumption that particular $L_{\mathrm{EX}, 8 \mathrm{~h}}$ is typical for $75 \%$ of all workplaces in that economic activity sector. Results of our study were compared to the findings of other authors. According to Haines et al. (2001), intensive noise causes the increase of accidents at work by $9 \%$ and number of errors by $6 \%$ respectively. The effects of noise were also reported in the research of Babisch (2000). It was concluded that even moderate noise levels as low as $50 \mathrm{~dB}(\mathrm{~A})$ causes adverse human reaction of sensitive people while the noise level of $70 \mathrm{~dB}(\mathrm{~A})$ increases the infarction risk by $45 \%$ if compared to the level of $50 \mathrm{~dB}(\mathrm{~A})$. Lusk et al. (2004) found that a $2-\mathrm{mm} \mathrm{Hg}$ increase in

Table 1. Values of the regression coefficient for the determination of statistical distribution of noise exposure

\begin{tabular}{|c|c|c|c|c|c|}
\hline \multirow{2}{*}{$\begin{array}{l}\text { Workplace categories in conformity } \\
\text { to the economic activity sector }\end{array}$} & \multicolumn{4}{|c|}{ Regression coefficients } & \multirow{2}{*}{$\begin{array}{l}\text { Determination } \\
\text { coefficient } R^{2}\end{array}$} \\
\hline & $a$ & $b$ & $c$ & $d$ & \\
\hline $\begin{array}{l}\text { Construction } \\
\text { - Manufacturing and installation of concrete and its } \\
\text { construction }\end{array}$ & 0.000298 & -0.02168 & -7.21088 & 663.2143 & 99.9 \\
\hline \multicolumn{6}{|l|}{ Manufacturing: } \\
\hline Food (including drinks) & -0.00087 & 0.138202 & -7.3423 & 230.1032 & 99.7 \\
\hline Wood processing and furniture trade & 0.006023 & -1.75421 & 165.3267 & -4980.93 & 98.3 \\
\hline Metal processing (without foundries) & 0.010628 & -2.97101 & 271.1111 & -8015.94 & 100 \\
\hline The garment industry & 0.019342 & -4.5761 & 353.8051 & -8879.85 & 99.8 \\
\hline Textile sector & 0.003205 & -0.89698 & 79.57921 & -2167.21 & 97.3 \\
\hline Transport - Workplaces of truck drivers & 0.008568 & -2.11194 & 167.8367 & -4237.88 & 96.8 \\
\hline $\begin{array}{l}\text { Agriculture and Forestry } \\
\text { - Workplaces of tractors and self-propelled agricultural } \\
\text { machinery }\end{array}$ & 0.018576 & -4.94195 & 431.3198 & -12290.8 & 99.7 \\
\hline $\begin{array}{l}\text { Electricity, water, gas and heat supply services } \\
\text { - Repair and maintenance }\end{array}$ & 0.000198 & -0.05748 & 3.701928 & 39.9483 & 99.9 \\
\hline
\end{tabular}

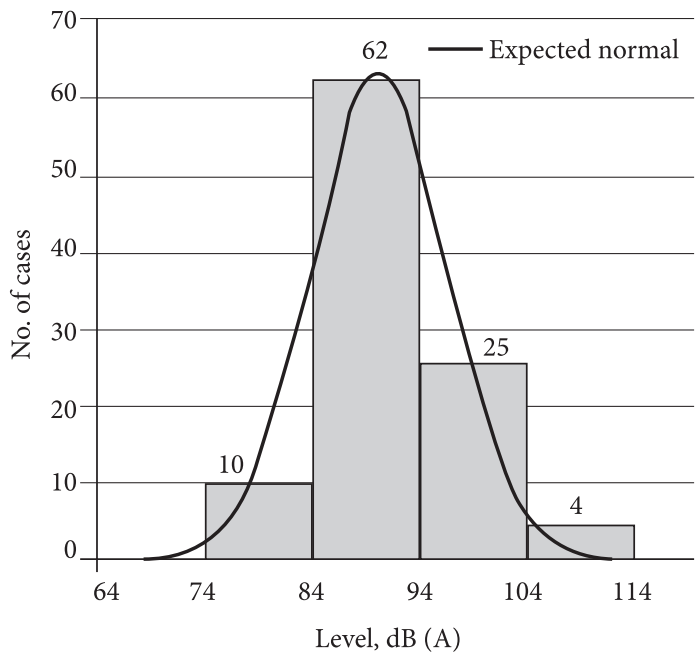

a)

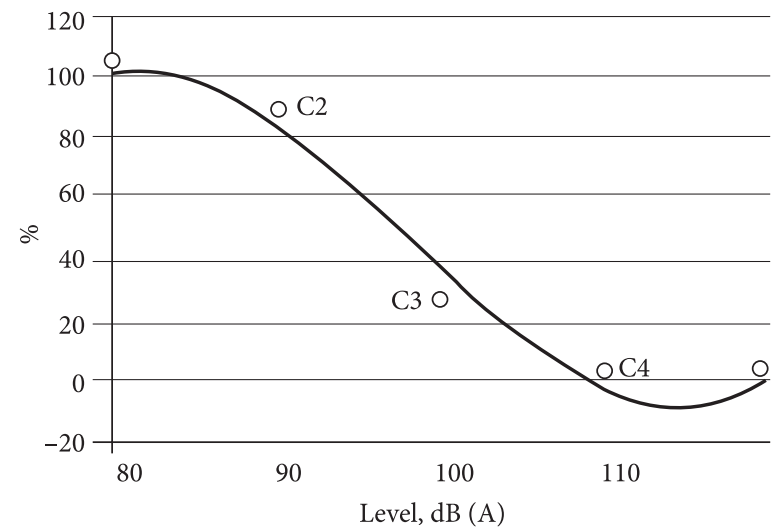

b)

Fig. 2. Histogram of the A-weighted SPL distribution in wood processing companies (a) and descending total percentage distribution and its polynomial expression (b) 
systolic blood pressure (SBP) was associated with each $10 \mathrm{~dB}(\mathrm{~A})$ increase in average noise, and a $2 \mathrm{~mm} \mathrm{Hg}$ increase in diastolic blood pressure (DBP) was associated with each $13 \mathrm{~dB}(\mathrm{~A})$ increase in average noise. This study showed that a long-term decrease of 5 to $6 \mathrm{~mm} \mathrm{Hg}$ in usual DBP was associated with 35-40\% less stroke and 20-25\% less coronary disease. Banbury and Berry (2005) discussed how concentration of office workers was affected that sound level of the office changed from $55 \mathrm{~dB}(\mathrm{~A})$ to $60 \mathrm{~dB}(\mathrm{~A})$. These results show that the noise risk at workplaces should be considered even if the level does not exceed the maximum permissible. McReynolds (2005) stated in his paper that approximately $10 \%$ of all workers are under the influence of intense (>85 $\mathrm{dB}(\mathrm{A}))$ noise. These results are in agreement with the results of Vilnius $\mathrm{Pu}$ blic Health Centre. They investigated 12457 workplaces in total and found that 3306 workers (27\%) work in noisy conditions. $18.5 \%$ from this number work under the noise varying from 75 to $85 \mathrm{~dB}(\mathrm{~A}), 4 \%$ under the conditions of $86-90 \mathrm{~dB}(\mathrm{~A})$ and $4 \%$ in the noise of $\geq 90 \mathrm{~dB}(\mathrm{~A})$. Results of these studies suggest that noise effects on workers and noise induced outcomes should be assessed even when the noise does not exceed the lower exposure value. Noise of $75 \mathrm{~dB}(\mathrm{~A})$ according to the recommendations of OSHA and NIOSH should be considered as risk factor to workers in at least $10 \%$ of all workplaces.

Total relative number $P\left(L_{p, x}\right)$ of the possible accident, health or hearing damage in separate sector of economic activity was described as the hundredth of total number of cases at various noise levels $L_{80,85,87}$ for $10 \%$ of workers as follows:

$$
P\left(L_{p, x}\right)=0,001 \cdot N_{L}
$$

The component 0.001 in Equation (2) is related to percentage indicator of all cases $(0.01)$ at considered sound pressure level which will give at least ten percent of workers affected. The prognostication of possible number of noise induced health impairment, accident or work-related error $\left(p_{H A E}\right)$ was described as a probability of independent events as follows:

$$
p_{H A E}=P\left(L_{p, 75}\right) \cdot P\left(L_{p, 76}\right) \ldots \cdot P\left(L_{p, 79}\right),
$$

where $P\left(L_{p, 75}\right) \ldots P\left(L_{p, 79}\right)$ - total relative number of cases in each group when the noise levels are in the range from $75 \mathrm{~dB}(\mathrm{~A})$ to $79 \mathrm{~dB}(\mathrm{~A})$ respectively.

For higher exposure levels, when the preventative value of $80 \mathrm{~dB}(\mathrm{~A})$ is reached, probability of noise induced hearing impairment $P_{H I}$ is described as follows:

$$
p_{H I}=P\left(L_{p, 80}\right) \cdot P\left(L_{p, 81}\right) \ldots \cdot P\left(L_{p, 84}\right)
$$

where $P\left(L_{p, 80}\right) \ldots P\left(L_{p, 84}\right)$ - total relative number of cases in each group when the noise levels are in the range from $80 \mathrm{~dB}(\mathrm{~A})$ to $84 \mathrm{~dB}(\mathrm{~A})$ respectively.

Considering the exposure limit value of $85 \mathrm{~dB}(\mathrm{~A})$ as a level where serious hearing loss may occur, its probability $P_{H L}$ can be proposed as follows:

$$
p_{H L}=P\left(L_{p, 85}\right) \cdot P\left(L_{p, 86}\right) \ldots \cdot P\left(L_{p, 90}\right),
$$

where $P\left(L_{p, 85}\right) \ldots P\left(L_{p, 90}\right)$ - total relative number of cases in each group when the noise levels are in the range from $85 \mathrm{~dB}(\mathrm{~A})$ to $90 \mathrm{~dB}(\mathrm{~A})$ respectively.

On the basis of noise exposure data at various economic activity sectors and Equations (3), (4) and (5), the indexes of various probabilities were determined. These results as probability index $\mathrm{p}$ stands for the risk situations in analogy with Moriyama and Ohtani (2009) and Aven et al. (2007) estimation as described in Table 2.

Table 2. Probability index $\mathrm{p}$ and its assessment criteria

\begin{tabular}{cl}
\hline Range of $p$ value & \multicolumn{1}{c}{ Assessment criteria } \\
\hline$\ldots-10^{-6}$ & Insignificant \\
$10^{-6}-10^{-5}$ & Normal working conditions \\
$10^{-5}-10^{-4}$ & Potentially risky situation \\
$10^{-4}-10^{-3}$ & Very risky situation \\
$10^{-3}-10^{-2}$ & Portentous situation \\
$10^{-2}-10^{-1}$ & Unacceptable \\
\hline
\end{tabular}

Value of probability index should be related to calculated probabilities $p_{H A E}, p_{H I}$ and $p_{H L}$ individually by attributing this number to one of suggested arbitrary assessment criteria. These criteria should outline the acoustic situation and were selected according to the practice used in safety systems. Considering that the $p$ value include two main parameters, i. e. noise level and number of workers (workplaces) affected it could be used for risk assessment in various objects where physical agent noise is prevailing.

\section{Results}

The results of accidents at work that are related with noise induced hearing impairment identify manufacturing as one of the most hazardous economic activity sectors. Noise exposure of $80 \mathrm{~dB}(\mathrm{~A})\left(\mathrm{N}_{80}\right)$ at wood processing and furniture manufacturing companies may be exceeded at $77 \%$ of all workspaces while $\mathrm{N}_{85}$ at $72 \%$ and $\mathrm{N}_{87}$ at $68 \%$ respectively (Fig. 3). In this regard, similar results and percentage distribution was found at individual wood processing company after the analysis of noise exposure levels where the level of $80 \mathrm{~dB}(\mathrm{~A})$ was exceeded at all workplaces. In 30 workplaces noise exposure level was between $80-85 \mathrm{~dB}(\mathrm{~A})$ while the noise of $85-90 \mathrm{~dB}(\mathrm{~A})$ was found at 250 workplaces and the level of $90-95 \mathrm{~dB}(\mathrm{~A})$ was exceeded at 3 workplaces.

According to the data provided by Vilnius Public Health Center the SPL's of wood processing machinery is as follows: universal machinery - 89-108 dB(A) (2 hour work shift at this level would give the $L_{\mathrm{EX}, 8 \mathrm{~h}}$ value of 
83-102 dB(A)), planer - 96-99 dB(A) (2 hour $L_{\mathrm{EX}, \text { sh }}=90-$ $93 \mathrm{dBA}$ ), double acting machinery $-84-88 \mathrm{~dB}(\mathrm{~A})$ (4 hour $\left.L_{\mathrm{EX}, 8 \mathrm{~h}}=81-85 \mathrm{~dB}(\mathrm{~A})\right)$, quadri acting machinery $-94 \mathrm{~dB}(\mathrm{~A})$ (2 hour $L_{\mathrm{EX}, 8 \mathrm{~h}}=88 \mathrm{~dB}(\mathrm{~A})$ ), saw-frame $-89 \mathrm{~dB}(\mathrm{~A})$, parquet production line - approx. $92 \mathrm{~dB}(\mathrm{~A})$. According to Davies et al. (2009) in lumber mills the noise mean predicted value was $91.7 \mathrm{~dB}(\mathrm{~A})$; minimum and maximum $-80.2 \mathrm{~dB}(\mathrm{~A})$ and $103.6 \mathrm{~dB}(\mathrm{~A})$ respectively.

Metal processing machinery and equipment also generates high levels of noise. The number of workplaces where $N_{80}$ is exceeded was $75 \%, N_{85}-67 \%$ and $N_{87}-61 \%$ (Fig. 3). In the research of Dutch researchers Granneman et al. (2004) the metal grinding $L_{\mathrm{EX}, 8 \mathrm{~h}}=93 \mathrm{~dB}(\mathrm{~A})$ over 1.5 hours, welding (over 3 hours) and pressing (over 6.5 hours) $L_{\mathrm{EX}, 8 \mathrm{~h}}=88 \mathrm{~dB}(\mathrm{~A})$, grinding with compressed air flow $L_{\mathrm{EX}, 8 \mathrm{~h}}=85 \mathrm{~dB}(\mathrm{~A})$ over 30 minutes.

According to the results obtained by measuring the noise levels at punch pressing company it was found that 100 (out of 200) workers were exposed to the noise level of $87-90 \mathrm{~dB}(\mathrm{~A})$ SPL, 80 workers to the noise of $90-95 \mathrm{~dB}(\mathrm{~A})$ SPL and 10 workers to the noise of more than $95 \mathrm{~dB}(\mathrm{~A})$. For the remaining 10 workplaces the noise level of lower than $85 \mathrm{~dB}(\mathrm{~A})$ was identified. Following values of noise measurements were found at the workplaces of metal forming, grinding and plastic shredding in the company of domestic appliances: 87-90 dB(A) - 8\%, 90-95 dB(A) $89 \%,>95 \mathrm{~dB}(\mathrm{~A})-3 \%$. Calculated $L_{\mathrm{EX}, \text { sh }}$ (over 2 hours) exceeded the lower exposure value in all cases and the limit value when the noise level was $>93 \mathrm{~dB}(\mathrm{~A})$.

The analysis of noise exposure at the companies of concrete and its construction manufacturing was done analogically. Noise level of $80 \mathrm{~dB}(\mathrm{~A})$ was exceeded at $75 \%$ of all places, $57 \%$ exceed the $85 \mathrm{~dB}(\mathrm{~A})$ and $51 \%-$ the limit value (Fig. 3). Noise exposure level for all these cases would be as high as $81-90 \mathrm{~dB}(\mathrm{~A})$ working only two hours per day. Similar results were found by Neitzel et al. (1999) at the construction sector in USA (workplaces of carpenters, metal construction assemblers, technicians and helpers). It was found that the upper exposure value of $85 \mathrm{~dB}(\mathrm{~A})$ was exceeded at $40 \%$ of all workplaces (out of 338 investigated).

Similar situation and results were found at the textile company, where the risk assessment was accomplished. From total number of 600 workers 200 were under the influence of $80-85 \mathrm{~dB}(\mathrm{~A})$ noise, 300 of $85-90 \mathrm{~dB}(\mathrm{~A})$ and 100 of $90-95 \mathrm{~dB}(\mathrm{~A})$ level noise. Generalized results at various workplaces are shown in Figs 3 and 4.

Agriculture is acknowledged as one of the most potentially harmful economic activity sectors worldwide. The analysis of noise exposure in the cabs of agricultural tractors and self-propelled agricultural machinery showed that $73 \%$ of these places exceed the value of $N_{80}$, $55 \%$ the $N_{85}$ and $46 \%$ of $N_{87}$ respectively. High number of noisy tractors can be justified by large number of tractors made in Belarus, Russia and Ukraine. This old machinery is prevailing in Lithuania (approx. 50\% of total number) and the noise levels at different models of tractors distributes as follows: MTZ-50/80/82 $\left(L_{\mathrm{EX}, \mathrm{sh}}=82 \mathrm{~dB}(\mathrm{~A})\right)$, $\mathrm{T}-150 \mathrm{~K}\left(L_{\mathrm{EX}, 8 \mathrm{~h}}=84 \mathrm{~dB}(\mathrm{~A})\right), \mathrm{T}-40 \mathrm{AM}$ and T-130 $\left(L_{\mathrm{EXX}, 8 \mathrm{~h}} \geq\right.$ $90 \mathrm{~dB}(\mathrm{~A})$.

The situation of noise exposure is slightly different in the sector of food and drink manufacturing. The lower exposure value of $80 \mathrm{~dB}(\mathrm{~A})$ was exceeded at $61 \%$, $85 \mathrm{~dB}(\mathrm{~A})$ at $53 \%$ and $87 \mathrm{~dB}(\mathrm{~A})$ at $48 \%$ of workplaces (Fig. 4). According to the statistical data provided by the British Health and Safety Executive the noise levels at the workplaces of bottle filling and packing varies from 85 to $95 \mathrm{~dB}(\mathrm{~A})$ and $95-100 \mathrm{~dB}(\mathrm{~A})$ at the workplaces of hammer mills. Noise measurement results at sewing workshops show that the level of $80 \mathrm{~dB}(\mathrm{~A})$ is exceeded at $41 \%$ of all workplaces, while approximately 10 percent of the workers were exposed to the noise of $85 \mathrm{~dB}(\mathrm{~A})$ and $1 \%$ to the noise level, higher than the exposure limit value.

The results from transportation sector and noise exposure measurements at truck driver workplaces show that the lower exposure value $N_{80}$ can be exceeded at $45 \%$ of workplaces, $\left(N_{85}\right)-23 \%$ and $\left(N_{87}\right)$ at $16 \%$ of all workplaces (Fig. 4). High percentage of workplaces affected is mainly caused by a large number of old CIS made machinery which usually lacks vibro-acoustic safety. Additional noise measurements were carried out in 9 workplaces of locomotive operators. Noise level varied within the level range from $76 \mathrm{~dB}(\mathrm{~A})$ to $90 \mathrm{~dB}(\mathrm{~A})$ and only approximate

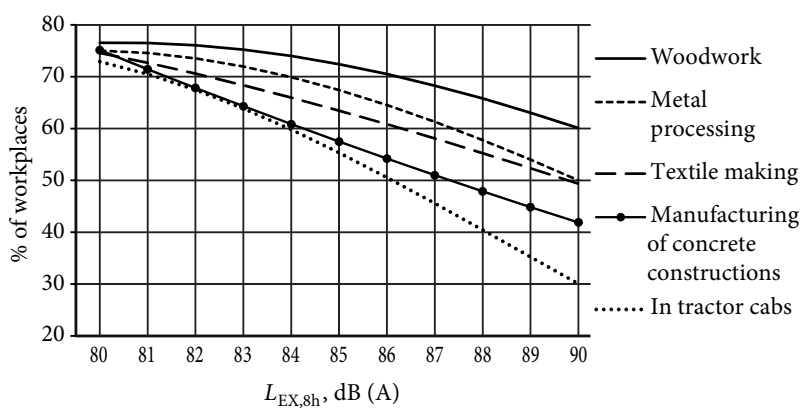

Fig. 3. Percentage of workplaces as a function of $L_{\mathrm{EX}, 8 \mathrm{~h}}$ at different sectors of economic activity

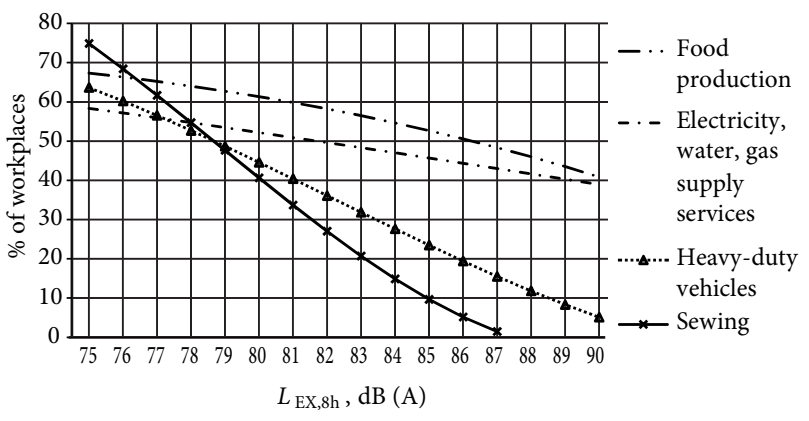

Fig. 4. Percentage distribution of workplaces as a function of noise exposure level normalized to a nominal 8 hour working day 
prognostication was considered according to the values of $N_{L}: N_{80}-55 \%, N_{85}-35 \%$ ir $N_{87}-27 \%$.

In the companies of water, gas, electricity and heat supply where the operators use typical equipment and tools prognosticated value $N_{80}$ is exceeded at $52 \%, N_{85}-$ $46 \%$ and $N_{87}-43 \%$ of all workplaces. According to the results provided by Vilnius Health Center compressor rooms and pump-houses are the noisiest workplaces where noise levels can be as high as 100-110 $\mathrm{dB}(\mathrm{A})$ $\left(L_{\mathrm{EX}, 8 \mathrm{~h}}=94-104 \mathrm{~dB}(\mathrm{~A})\right.$ over 2 hours $)$. Hacksawing and wringing are also frequent operations at these workplaces when the SPL is as high as $90-100 \mathrm{~dB}(\mathrm{~A})$ for hacksawing and $82-89 \mathrm{~dB}(\mathrm{~A})$ for wringing respectively.

The results reviewed above show that the exposure limit value of $87 \mathrm{~dB}(\mathrm{~A})$ is exceeded at the workplaces of wood processing equipment (77\%), metal processing workshops (forges, metal pressing and formation) approx. $61 \%$, textile production (58\%). The noise exposure values of slightly lower risk on workers were found at the workplaces of concrete and its construction (51\%), tractor drivers (46\%), food making and public utilities (approx. 43\%).

Special attention should be addressed to these workplaces where parameter $L_{\mathrm{EX}, 8 \mathrm{~h}}$ is calculated for lower effective durations of the working day than the reference duration of 8 hours. This might give uncertainty at various durations therefore $L_{\mathrm{EX}, 8 \mathrm{~h}}$ was calculated for ordinary work operation durations at particular economic activities.
Noise effect on workers was assessed by performing probability analysis when the accident can occur or hazard to health or hearing is credible. As a result of these impairments probability index was determined for above mentioned economic activity sectors (Table 3 ). Percentage of workplaces was calculated for the levels of 80,85 and $87 \mathrm{~dB}(\mathrm{~A})$ while the calculations of probability index $\mathrm{p}$ was performed by using Equations (3), (4) and (5).

Considering the annotation in EU directive that exposure limit value can be lowered if the personal hearing protection is used, actual noise exposure can be decreased to lower exposure value of $80 \mathrm{~dB}(\mathrm{~A})$ or even more. However a major problem rises fulfilling the agreement for the preventative actions when lower and upper exposure values are exceeded. The attenuation effect of hearing protection is then not considered and employee is obliged to apply any other preventative actions such as replacement of noisy machinery or equipment, shielding it, re-managing the workplace or to apply organizational restructuration (shorten work shift duration, managing breaks) and to improve the occupational understanding of work safety. However the priority should be oriented towards technical solutions.

Calculated values of hearing loss probability index in Table 3 indicate that risky conditions should be expected at wood processing $(p=0.0087)$, metal processing (0.0042) and textile (0.0032) sectors while less risky in construction (0.0014) and food processing (0.0011).

Table 3. Data of percentage distribution and probability index at various economic activity sectors for the $L_{\text {ex, } 8 \mathrm{~h}}$ of $80 \mathrm{~dB}(\mathrm{~A})$, $85 \mathrm{~dB}(\mathrm{~A})$ and $87 \mathrm{~dB}(\mathrm{~A})$ respectively

\begin{tabular}{|c|c|c|c|c|c|c|}
\hline \multirow[b]{2}{*}{$\begin{array}{l}\text { Sector of economic activity } \\
\text { and particular workplaces }\end{array}$} & \multicolumn{3}{|c|}{$\begin{array}{l}\text { No. of workplaces, where the noise } \\
\text { exposure levels }\left(N_{L}\right) \text { may be exceeded,\% }\end{array}$} & \multicolumn{3}{|c|}{ Probability index $(p)$} \\
\hline & $N_{80}$ & $N_{85}$ & $N_{87}$ & $\begin{array}{l}\text { Health impair- } \\
\text { ment, accident } \\
\text { or work- } \\
\text { related error } \\
\left(L_{75} \ldots L_{79}\right) \\
\end{array}$ & $\begin{array}{l}\text { Hearing } \\
\text { impairment } \\
\left(L_{80} \ldots L_{84}\right)\end{array}$ & $\begin{array}{l}\text { Hearing } \\
\text { loss } \\
\left(L_{85} \ldots L_{90}\right)\end{array}$ \\
\hline \multicolumn{7}{|l|}{ Manufacturing: } \\
\hline $\begin{array}{l}\text { Wood processing and furniture } \\
\text { manufacturing }\end{array}$ & 77 & 72 & 68 & $-^{*}$ & 0.0248 & 0.00869 \\
\hline Metal processing (without foundries) & 75 & 67 & 61 & $-{ }^{*}$ & 0.0207 & 0.00416 \\
\hline Textile industry & 75 & 63 & 58 & 0.0304 & 0.0173 & 0.00320 \\
\hline Food processing (including drinks) & 61 & 53 & 48 & 0.0117 & 0.0066 & 0.00105 \\
\hline The garment industry & 41 & 10 & 1 & 0.0083 & 0.0010 & - \\
\hline $\begin{array}{l}\text { Construction - Manufacturing of concrete } \\
\text { and installation of its construction }\end{array}$ & 75 & 57 & 51 & 0.0484 & 0.0143 & 0.00143 \\
\hline Transport - Workplaces of truck drivers & 45 & 23 & 16 & 0.0056 & 0.0006 & - \\
\hline $\begin{array}{l}\text { Agriculture and Forestry - Drivers of } \\
\text { tractors and self-propelled agricultural } \\
\text { machinery }\end{array}$ & 73 & 55 & 46 & $-^{*}$ & 0.0133 & 0.00055 \\
\hline $\begin{array}{l}\text { Electricity, water, gas and heat supply } \\
\text { services - repair and maintenance }\end{array}$ & 52 & 46 & 43 & 0.0055 & 0.0030 & 0.00057 \\
\hline
\end{tabular}

* Note: unspecified but supposedly $>0.04$. 
Acoustic situation for hearing impairment in these sectors as well as in agricultural tractors $(p=0.013)$, construction $(0.014)$ and textile industry (0.017) were identified as portentous. Lowest expected noise risk index values were at transport, electricity, water, gas and heat supply services, and garment industry.

The results of our study and in the researches of other authors create theoretical premises to prognosticate the approximate number of workplaces, where the noiserelated risk is prevailing. According to the distribution of this data at different economic activity sectors it becomes reasonable to apply preventative actions for the noise reduction or workers' protection.

\section{Conclusions}

On the base of statistical data and using the methods of mathematical statistics a model for the prediction of noise exposure was created at workplaces of different economic activity sectors. This model allowed to predict the percentage distribution of workplaces where the noise exposure levels of 80,85 and $87 \mathrm{~dB}(\mathrm{~A})$ were exceeded.

Highest number of noise level at workplaces was found at the companies of wood processing and furniture manufacturing. The exposure value of $80 \mathrm{~dB}(\mathrm{~A})$ was exceeded at $77 \%, 85 \mathrm{~dB}(\mathrm{~A})-72 \%$ and $87 \mathrm{~dB}(\mathrm{~A})-68 \%$ of all workplaces. Similar results were found at the workplaces of metal processing where the results were as follows: $N_{80}-75 \%, N_{85}-67 \%$ and $N_{87}-61 \%$.

Highest risk probability on workers to undergo the NIHL was found at the workplaces of wood, metal and textile sectors (probability index from 0.0087 to 0.0032 respectively). Construction sector and operation of agricultural tractors should be also attributed as having potential risk on workers.

Noise induced health impairment and accidents or work-related errors were identified as portentous in construction sector and agricultural tractors, wood and metal processing companies (probability index 0.04), textile sector (0.03) and food processing (0.012).

\section{References}

Arezes, M. P.; Miguel, A. S. 2005. Hearing protection use in industry: the role of risk perception, Safety Science 43(4): 253-267. http://dx.doi.org/10.1016/j.ssci.2005.07.002

Aven, T.; Vinnem, J. E.; Wiencke, H. S. 2007. A decision framework for risk management, with application to the offshore oil and gas industry, Reliability Engineering and System Safety 92(4): 433-448.

http://dx.doi.org/10.1016/j.ress.2005.12.009

Babisch, W. 2000. Traffic noise and cardiovascular disease: epidemiological review and synthesis, Noise Health 2(8): 9-32.

Baltrènas, P.; Petraitis, E.; Januševičius, T. 2010. Noise level study and assessment in the southern part of Panevežys, Journal of Environmental Engineering and Landscape Management 18(4): 271-280. http://dx.doi.org/10.3846/jeelm.2010.31

Banbury, S. P.; Berry, D. C. 2005. Office noise and employee concentration: identifying causes of disruption and potential improvements, Ergonomics 48(1): 25-37. http://dx.doi.org/10.1080/00140130412331311390

Cagno, E.; Di Giulio, A.; Trucco, P. 2005. Statistical evaluation of occupational noise exposure, Applied Acoustics 66: 297-318. http://dx.doi.org/10.1016/j.apacoust.2004.08.001

Davies, H. W.; Teschke, K.; Kennedy, S. M.; Hodgson, M. R.; Demers, P. A. 2009. Occupational noise exposure and hearing protector use in Canadian lumber mills, Journal of Occupational and Environmental Hygiene 6(1): 32-41. http://dx.doi.org/10.1080/15459620802548940

Granneman, J. H.; Oostdijk, J. P. J.; Schermer, F. A. G. M. 2004. Extensive survey of occupational noise exposure in the metal working industry, in The Proceedings of Inter Noise 2004: Progress in Noise Control for the 21st Century/The 33rd International Congress and Exposition on Noise Control Engineering, 22-25 August, 2004, Prague, 1-8.

Haines, M. M.; Stansfeld, S. A.; Job, R. F. S.; Berglund, B.; Head, J. 2001. Chronic aircraft noise exposure, stress responses mental health and cognitive performance in school children, Psychological Medicine 31: 265-277.

http://dx.doi.org/10.1017/S0033291701003282

Ising, H.; Kruppa, B. 2004. Health effects caused by noise: Evidence in the literature from the past 25 years, Noise \& Health 6(22): 5-13.

ISO 1999:2013. Acoustics - Estimation of noise - induced hearing loss.

ISO 9612:2009. Acoustics - Determination of occupational noise exposure - Engineering method.

Lusk, S. L.; Gillespie, B.; Hagerty, B. M.; Ziemba, R. A. 2004. Acute effects of noise on blood pressure and heart rate, Archives of Environmental Health: An International Journal 59(8): 392-399.

http://dx.doi.org/10.3200/AEOH.59.8.392-399

McReynolds, M. C. 2005. Noise-induced hearing loss, Medical Journal 24(2): 73-78. http://dx.doi.org/10.1016/j.amj.2004.12.005

Merkevičius, S.; Strelkauskis, R.; Butkus, R. 2011. Metodologiniai mobilių mašinų generuojamų vibracijų operatoriui keliamos rizikos nustatymo aspektai [Methodological aspects of evaluation of vibration risk on the operators of mobile machinery], in The Proceedings of the International Scientific Conference "Human and Nature Safety 2011", 11-13 May, 2011, Akademija, Lithuania, 39-41.

Miyakita, T.; Ueda, A.; Futatsuka, M.; Inaoka, T.; Nagano, M.; Koyama, W. 2004. Noise exposure and hearing conservation for farmers of rural Japanese communities, Journal of Sound and Vibration 277(3): 633-641. http://dx.doi.org/10.1016/j.jsv.2004.03.026

Moriyama, T.; Ohtani, H. 2009. Risk assessment tools incorporating human error probabilities in the Japanese small-sized establishment, Safety Science 47: 1379-1397. http://dx.doi.org/10.1016/j.ssci.2009.01.005

Neitzel, R.; Seixas, N. S.; Camp, J.; Yost, M. 1999. An assessment of occupational noise exposures in four construction trades, American Industrial Hygiene Association Journal 60(6): 807817. http://dx.doi.org/10.1016/j.jsv.2004.03.026 
Oksa, P.; Palo, L.; Saalo, A.; Jolanki, R.; Mäkinen, I.; Kauppinen, T. 2012. Ammattitaudit ja ammattitautiepäilyt 2010. Työperäisten sairauksien rekisteriin kirjatut uudet tapaukset [Occupational Diseases and suspected Occupational Diseases 2010. New cases registered in the Register of Occupational Diseases] [online], [cited 5 June 2013]. Available from Internet: http://www.ttl.fi/fi/verkkokirjat/ammattitaudit/Documents/Ammattitaudit_2010.pdf

Oškinis, V.; Kinduryte, R.; Butkus, D. 2004. Automobilių triukšmo tyrimų magistralëje Vilnius-Kaunas-Klaipèda rezultatai [Evaluation of car noise on the highway VilniusKaunas-Klaipeda], Journal of Environmental Engineering and Landscape Management 12(1): 10-18.

http://dx.doi.org/10.1016/S0022-4375(00)00039-6
Selander, J.; Nilsson, M. E.; Bluhm, G.; Rosenlund, M.; Lindqvist, M.; Nise, G.; Pershagen, G. 2009. Long-term exposure to road traffic noise and myocardial infarction, Epidemiology 20(2): 272-279. http://dx.doi.org/10.1097/EDE.0b013e31819463bd

Vasarevičius, S.; Graudinyte, J. 2004. Transporto triukšmo lygio automobilių kelių ir geležinkelio sankirtose tyrimai ir ivertinimas [Investigation and evaluation of noise level at motorway and railway crossings], Journal of Environmental Engineering and Landscape Management 12(1): 19-24.

Yränheikki, E.; Savolainen, H. 2000. Occupational safety and health in Finland, Journal of Safety Research 31(4): 177-183.

Ričardas BUTKUS, Dr Assoc. Professor at the Institute of Agricultural Engineering and Safety, Aleksandras Stulginskis University (ASU). Publications: single-authored of co-written more than 50 scientific articles. Research interests: environment and mechanics engineering, occupational safety and ergonomics, sound and vibration.

Alvidas ŠARLAUSKAS, Lecturer at the Institute of Agricultural Engineering and Safety, Aleksandras Stulginskis University. Doctor of Sciences (Environmental Engineering and Landscape Management), ASU, 2000. Publications: author of $>10$ scientific research papers. Research interests: standardization, occupational safety, physical measurements.

Gediminas VASILIAUSKAS, Junior Researcher at the Institute of Agricultural Engineering and Safety, Aleksandras Stulginskis University. Doctor of Sciences (Environmental Engineering and Landscape Management), ASU, 2012. Publications: author of 10 scientific research papers. Research interests: environmental protection, occupational safety, sound quality, speech intelligibility. 